\title{
INFECTION BY HPV IN THE ORAL CAVITY - A LITERATURE REVIEW
} INFECÇÃO POR HPV NA CAVIDADE ORAL - REVISÃO DA LITERATURA

\author{
Luciana Barros Augé1, Bruno Bier Martinazzo², Paula Kohler Carpilovsky³, \\ Cristiane Kohler Carpilovsky ${ }^{4}$, Luciana Maria Fontanari Krause ${ }^{5}$
}

\begin{abstract}
Human papillomavirus (HPV) is a microorganism that has the potential to infect the skin and mucous membranes, causing local tissue injury or remaining asymptomatic. When one's immune system is not capable of fighting an invasion of the virus, it remains latent inside the nucleus of infected cells. One of the clinical manifestations is the presence of benign epithelial lesions in the oral cavity, which include squamous cell papilloma, common skin warts, focal epithelial hyperplasia and papillary hyperplasia. Human papillomaviruses have an etiological role in cancers of the pharynx and the oral cavity, with $25-50 \%$ of cases being attributed to HPV infections. A literature review was carried out in big contemporary databases and included papers from any year of publishing, going back as far as reviewing the history of its viral taxonomic classification all the way to current clinical approaches and therapies to patients with this infection, as well as immunization strategies with vaccines. It has been observed that the development of oropharyngeal cancer in a younger and non-smoking population could be attributable to HPV as an independent causal factor and has been a subject of increasing interest for the research community. HPV vaccination is expected to impact oral HPV incidence rates, leastwise for the genotypes included in the vaccine.
\end{abstract}

Keywords: DNA, Genome, Papillomavirus.

\section{RESUMO}

O papilomavírus humano (HPV) é um microrganismo com potencial para infectar a pele e as membranas mucosas, causando lesão tecidual local ou permanecendo assintomático. Quando o sistema imunológico de uma pessoa não é capaz de lutar contra uma invasão do vírus, ele permanece latente dentro do núcleo das células infectadas. Uma das manifestações clínicas é a presença de lesões epiteliais benignas na cavidade oral, que incluem papiloma de células escamosas, verrugas cutâneas comuns, hiperplasia epitelial focal e hiperplasia papilar. Os papilomavírus humanos têm um papel etiológico nos cânceres da faringe e da cavidade oral, com 25-50\% dos casos sendo atribuidos a infecções por HPV. Uma revisão da literatura foi realizada em grandes bancos de dados e incluiu artigos de qualquer ano de publicação, desde a revisão da história de sua classificação taxonômica viral até as abordagens clínicas atuais e terapias para pacientes com esta infecção, bem como estratégias de imunização com vacinas. Foi observado que o desenvolvimento de câncer orofaríngeo em uma população mais jovem e não fumante pode ser atribuída ao HPV como um fator causal independente e tem sido um assunto de crescente interesse para a comunidade cientifica. A vacinação contra o HPV deve afetar as taxas de incidência de HPV oral, pelo menos para os genótipos incluidos na vacina.

\section{Palavras-Chaves: DNA, Genoma, Papiloma virus}

\footnotetext{
${ }^{1}$ Autora. Otorrinolaringologista e Mestranda em Ciências da saúde e vida (UFN). E-mail:lubauge@hotmail.com

${ }^{2}$ Colaborador. Acadêmico de Medicina (UFN). E-mail: bruno.m.bier@gmail.com

${ }^{3}$ Colaboradora. Acadêmica de Medicina (UFN). E-mail: kohlerc.paula@gmail.com

${ }^{4}$ Colaboradora. Professora do Departamento de Morfologia (UFSM) E-mail: criscarpila@gmail.com

${ }^{5}$ Orientadora. Professora Colaboradora do Mestrado em Ciências da Saúde e orientadora do projeto e da Vida (UFN); Professora Adjunta do Departamento de Morfologia (UFSM). E-mail: lfontanari@yahoo.com.
} 


\section{INTRODUCTION}

The human papillomavirus (HPV) is a small ( $55 \mathrm{~nm})$, non-enveloped, icosahedral shaped virus, with a natural tropism or predilection to infect epithelial cells (HA; CALIFANO, 2004). It can cause tissue lesions or remain in a dormant non-replicative state (BERNARD et al., 2010). More than 200 types of HPV have already been identified, all capable of infecting skin cells or cells of mucous membranes. They are divided into high and low risk subtypes (HÜBBERS; AKGÜL, 2015).

The HPV infection is basically transmitted through any sexual contact (FERNANDES et al., 2013) both men and women are susceptible to the infection, and can be asymptomatic carriers, transmitters and affected by the infection, all at once in some cases (TRISTÃO et al., 2012). Among all of the risk factors for HPV infection, the following stand out: having a high number of sexual partners, tobacco use, alcohol consumption, early age of sexual activity initiation and use of oral hormonal medications (FERNANDES et al., 2013; GASPAR et al., 2015; SANTOS, et al., 2016).

HPV has the molecular mechanisms necessary to infect the cells of the basal layer of the epithelium, when there is solution of continuity of the outermost layer of the skin. Although most often the virus is eliminated by the immune system, not leading to clinical disease. When the immune response is insufficient, the virus enters a quiescent state, and remains dormant inside the nuclei of the infected cells (HORMIA et al., 2005; HENNESSEY; WESTRA; CALIFANO, 2009).

One of the clinical manifestations is the presence of benign epithelial lesions in the oral cavity, those which include squamous cell papilloma, condyloma acuminatum, common warts, focal epithelial hyperplasia and papillary hyperplasia (ABBEY et al., 1980). Oral squamous papiloma is the most frequently presented lesion and occurs evenly among genders, predominantly in the tongue and soft palate (FERRARO et al., 2011).

In the oral cavity, HPV subtypes are classified according to their respective oncogenic risk, subtypes 6 and 11 are considered low risk variants and are associated with benign oral lesions, such as warts, condyloma acuminatum, papilloma, and focal epithelial hyperplasia. High risk subtypes such as HPV 16 and 18, on the other hand, are frequently associated with squamous cell carcinoma and precancerous lesions with a high risk of malignization (D'SOUZA et al., 2007).

Human papillomaviruses play an etiological role in cancers of the oropharynx, with $25-50 \%$ of cases being attributed to HPV infections (DE MARTEL et al., 2017; CHATURVEDI et al., 2013). In particular, the incidence of cancerous lesions in a younger, non-smoking population has raised the attention of the research community (ZAMMIT et al., 2018).

Currently, the two most frequently used methods to detect the viral genome are the hybrid capture method and polymerase chain reaction (PCR) with generic primers. There is no knowledge reliable method that can determine causality between the presence of the virus and the disease, 
although its presence is highly suggestive (HUBBARD, 2003). Vaccinating against HPV is expected to have an impact on the rates of incidence of oral HPV, lowering the prevalence of HPV genotypes 6, 11, 16 as well as 18. Which are included in the vaccine (BROUWER et al., 2015).

A literature integrative review was carried out in big contemporary databases and included papers from any year of publishing, going back as far as reviewing the history of its viral taxonomic classification all the way to current clinical approaches and therapies to patients with this infection, as well as immunization strategies (old and new) with vaccines. The term oral papilloma was used, articles that searched for HPV in malignant tumors were exclused.

\section{PAPILOMAVIRUSES}

The human Papillomavirus is characteristically small (55nm), non-enveloped, icosahedral in shape, with a natural predilection, or tropism, for infecting epithelial cells (HA; CALIFANO, 2004). It infects the epithelium of some vertebrates, including humans, where it remains asymptomatic/ quiescent or may evoke symptoms (BERNARD et al., 2010). Complete genomes of the Papillomaviridae family were identified in 1949 (STRAUSS et al., 1949).

In 1963, HPV's viral genome was unveiled. (CRAWFORD, 1963). Its DNA was purified from wart samples. The physical maps of the length of base pairs in generated genomes were compiled (FAVRE et al., 1975). In one of the first conventions on papillomaviruses, Coggin and Zur Hausen, making an attempt to unify nomenclature, established that the Human Papilomaviruses would be attributed a given number, in the order in which their discovery was published. Hence, the first isolate would be their prototype. Also, a new type of HPV could be labeled if any new circular double stranded DNA molecule with less than $50 \%$ of base pair similarity to other previously labeled HPV types, was discovered. The similarity should be determined using liquid hybridization methods, under strict conditions. All HPV types had at least six "early" genes (E1 - E7) and two "late" genes (L1, L2), as well as a loci known as regulatory regions (DE VILLERS, 2013).

HPV was also found in reptiles, birds and other mammals. Thence, the heterogeneity of species found to be susceptible to this virus reflects not only the velocity in which the pathogen acquired its genomic mutations, but also a notably antique story of adaptations to specific host cells, and hostmediated control of infections (DE VILLERS et al., 2004).

Over 200 HPV types were already identified, they're grouped in 5 genera (Alphapapillomavirus, Betapapillomavirus, Gammapapillomavirus, Mu papillomavirus and Nu papillomavirus) and are also divided in high and low risk HPVs, according to their oncogenic risk. HPVs can also be divided in regard to their tropism for particular tissue types, being divided as mucous or cutaneous (HÜBBERS; AKGÜL, 2015). 


\section{GENOTYPE \& SUBTYPE CLASSIFICATION}

About 30 years ago, the labeling and subdivision of HPV types was initiated, but the absence of a reliable cell culture system to replicate this virus, postponed its taxonomic classification. (DE VILLERS et al., 2004). New techniques have allowed the discovery of new viral types. (DE VILLERS, 2013).

The strict fastidiousness of papillomaviruses to replicate on the terminal differentiation of keratinocytes, initially hampered its proper study and classification. At first, it was impossible to propagate virions in cell culture, and viral yields from natural lesions were low, with few exceptions. The use of DNA-free virus-like particles (VLPs), virions generated in organotypic cultures and pseudovirions containing plasmid markers, which were generated using heterologous expression or cell-free packaging systems, helped partially to overcome this problem (BIENKOWSKA-HABA; SAPP, 2011).

In addition, papillomaviruses do not elicit expressive antibody response, which prevented classification based on "serotype" designation (BERNARD et al., 2010; OLIVEIRA et al., 2018).

There was an attempt to recognize the official classification for papillomaviruses by the International Committee on Taxonomy of Viruses (ICTV) in the 1980s, but only in 2003 with the classification based on the similarity of the sequences, it was finally accepted (DE VILLERS, 2013). Knowledge of the conserved L1 gene led to the development of primers for its use in taxonomic classification into types and subtypes (MANOS et al., 1989). Papillomavirus genotypes were classified according to the L1 gene, which encompasses a preserved open reading frame (ORF). Similarity of at least $90 \%$ of the L1 nucleotide sequence characterizes the viral type (genus) and the discrepancy of 2 to $10 \%$ in the sequence code classifies a subtype (species).

Claude Fauquet et al. (2003) had an essential role in the preparation of the proposal (including 96 types of HPV and 22 animal viruses), and influenced the final decision of the ICTV (International Committee on Taxonomy of Viruses), in which the classification of the Papillomaviridae family was accepted as it currently is today (DE VILLERS et al., 2004). De Villers et al. (2004) described the topology of phylogenetic trees, set quantitative thresholds in analyses of nucleotide sequences and biologically distinctive characteristics (host species, target tissues, pathogenicity, genome organization) that ultimately determine the classification of these viruses at the genus level. A nomenclature of these genera based on the Greek alphabet was introduced and quickly became accepted and widely used by the ICTV and the papillomavirus research community.

In 2004, sixteen papillomavirus or individual groups met the genera criterion, and the Greek alphabet from the letters alpha to pi was used to create their nomenclature. Human papillomaviruses were then separated in five genera (Alpha, Beta, Gamma, Mu and Nu-PVs) and the two remaining 
genera (Eta- and Theta-PVs) comprised a single bird papillomavirus (FAUQUET et al., 2005; BERNARD et al., 2010).

Low-risk HPVs can cause tissue lesions on the skin and mucous membranes, including the oral mucosa (RATAUVA e SYJÄNEN, 2011). Among types considered to be of low risk, are subtypes HPV-6, HPV-11, HPV-40, HPV-43, HPV-44, HPV-54, HPV-61, HPV-70, HPV-72, HPV-81 (MUÑOZ et al., 2003). HPV-6 shows a preference for genital sites, compared to HPV-11, which is the most prevalent type in oral sites (EGAWA et al., 2015). High-risk HPVs are also called oncogenic. Among some types considered to be high risk are HPV-16, HPV-18, HPV-31, HPV-33, HPV-35, HPV-39, HPV-45, HPV-51, HPV-52, HPV-56, HPV -58, HPV-59, HPV-66, HPV-68, HPV-69, HPV-73, HPV-82 (WAGGONER, 2003). HPV-16 is mostly associated with tumors in the oral cavity and pharynx. (EGAWA et al., 2015). Subtypes HPV-7 and HPV-2 are associated with the emergence of skin warts (LETO et al., 2011).

Table 1 summarizes the history of studies researched in the literature that represent the evolution of advances in the classification of Papillomaviruses.

Table 1 - Advances in the classification of Papillomavirus demonstrated by studies in the literature.

\begin{tabular}{ll}
\hline \multicolumn{1}{c}{ Study author and year of publishing } & \multicolumn{1}{c}{ Classification advancement } \\
\hline MANOS et al., 1989 & Applicability of primer usage in viral typification \\
\hline FAUQUET et al., 2003 & 96 types described in the ICTV \\
DE VILLERS et al., 2004 & Reviewed proposal of classification with 118 described types \\
\hline BERNARD et al., 2010 & Report of serotype specific response absence \\
BIENKOWSKA-HABA; SAPP, 2011 & Use of DNA free viral-like particles (VLP) \\
DE VILLERS, 2013 & Review of classification with 170 reported types \\
OLIVEIRA et al., 2018 & Recent report of new subtypes \\
KOONIN et al., 2020 & Mega taxonomy proposal for viruses \\
\hline & Source: Author \\
\hline
\end{tabular}

\section{GENOMIC STRUCTURE}

Papillomaviruses have a circular double stranded DNA genome of approximately $8 \mathrm{~kb}$ (8000 base pairs), enclosed by a 72 capsomere capsid and typically accommodating eight genes (BERNARD et al., 2010). They replicate their genome inside the nucleus of host cells, behaving as obligate intracellular parasites with specific tropism for keratinocytes. (GANGULY, PARIHAR, 2009).

Their genome is composed of six genes that are expressed early (E) and two that are expressed later on in the replication process (L) (LONGWORTH, LAIMINS, 2004; PSYRRI, DIMAIO, 2008).

The E region is expressed soon after infection, and codes for proteins responsible for promoting and regulating DNA synthesis. It is encompassing genes E1, E2, E4, E5, E6 and E7. The L region codes for proteins in the viral icosahedral capsid, and is formed by genes L1 and L2. In between the 
$\mathrm{L}$ and $\mathrm{E}$ regions, is the long control-region (LCR), that does not code for any proteins, but regulates viral transcription (SOUZA; GONÇALVES, 2009; SUN et al., 2009).

The L1 and L2 proteins are encoded in the late region and are responsible for forming the viral capsid. The capsid is composed of 360 molecules of the L1 protein, which are arranged in 72 capsomeres organized in pentameric structures, and 12 molecules of the L2 protein (BIENKOWSKA-HABA; SAPP, 2011). The L1 protein has multiple functions; one of them is mediating the viral binding to the cell surface, while the L2 protein is responsible for programming the inclusion of the viral genome in the capsid, hence promoting the assembly of the virion (FAY et al., 2004; STAUFFER et al., 1998).

The E region genes encode three oncoproteins, E5, E6 and E7. The E5 protein is responsible for cellular alterations and has a role in viral DNA replication (FERNANDES et al., 2013; MORSHED et al., 2014). Proteins E6 and E7 are associated with malignant transformation by the action of HPV and cause impairment of the regulation of the cellular cycle. (MORSHED et al., 2014).

Proteins E1, E2 and E4 are regulatory proteins. E1 playing a role in genome replication while E2 modulates viral transcription and E4 controls replication and promotes viral release (EGAWA et al., 2015; MORSHED et al., 2014).

\section{INFECTION CHARACTERISTICS}

The entry of HPV into the host cell depends on the binding of heparin sulfate onto the host's basement membrane, this binding trigger conformational changes that affect structural proteins L1 and L2. These changes are a prerequisite for the entry of HPV into the cell (SAPP; BIENKOWSKA-HABA, 2009). Viral entry occurs through endocytosis, resulting in the installation of the viral infection. After infection, the viral genomes are maintained at a low number of copies and gene expression is both regulated by and dependent on the differentiation of cells infected by HPV.

HPV has the potential to infect cells in the basal layer of the epithelium only when there is solution of continuity, and most infections are eliminated by the immune system, not resulting in clinical disease. When the immune system cannot control the invasion of the virus, it remains latent in the nucleus of infected cells (HORMIA et al., 2005; HENESSEY; WESTRA; CALIFANO, 2009). HPV replication occurs in cells in the basal and parabasal layers of the epithelium, sites where only early genes are transcribed. Extensive replication of viral DNA and transcription of all viral genes, as well as capsid formation, occur only in the most superficial layers of the epithelium, forming eosinophilic inclusions and a characteristic cellular lesion pattern (BUSTOS et al., 2001), with the presence of perinuclear halos; in addition to a many histological changes, such as the presence of superficial cells with nuclear atypia's in regards of size and shape (HA; CALIFANO, 2004). As represented in panels A through D in Figure 1. 
Figure 1 - Visual representation of the many stages of viral entry and viral proliferation inside the epithelial cells.
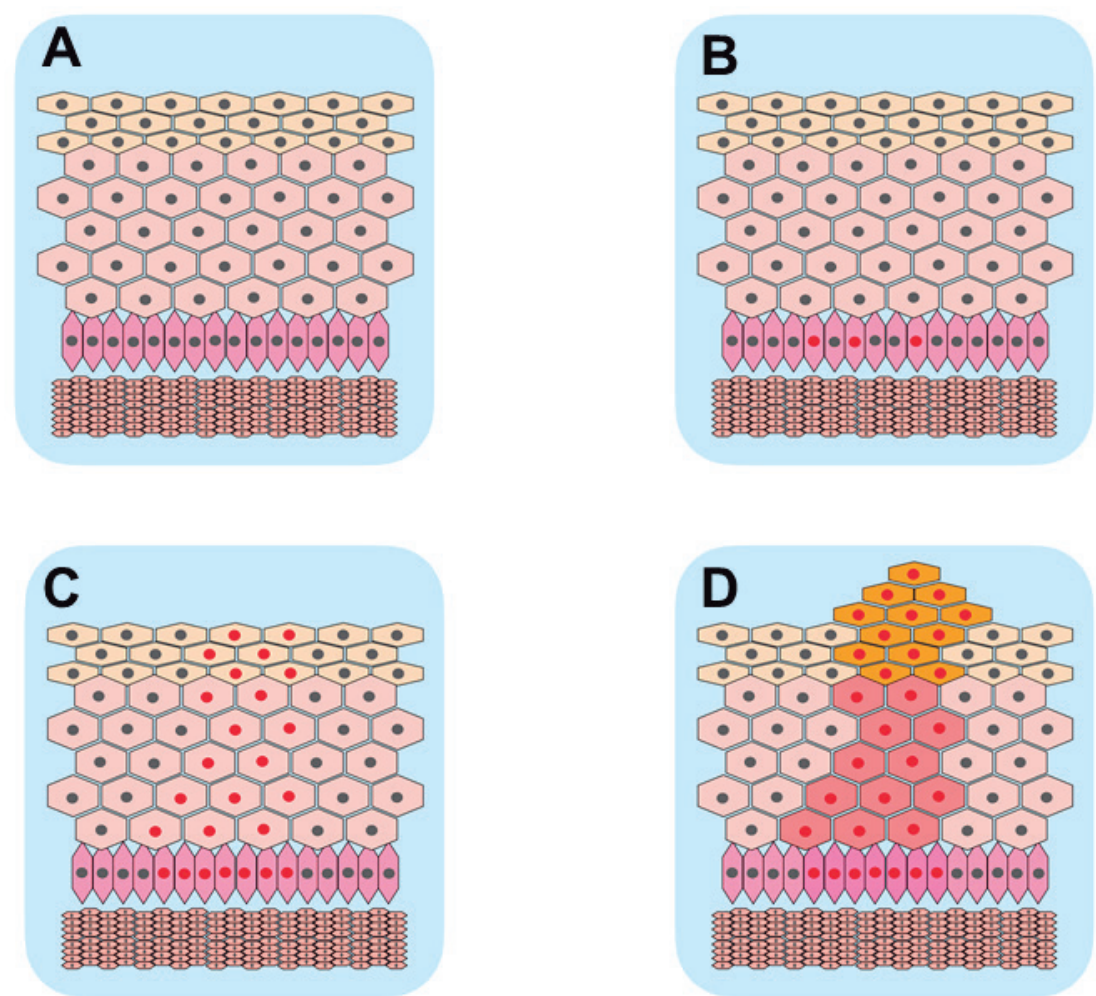

$\mathbf{A}=$ Normal epidermic cell; $\mathbf{B}=$ Latent HPV infection, red dots represent viral DNA; $\mathbf{C}=$ Viral replication in the basal layer, red dots represent spread of viral DNA throughout the epidermis; $\mathbf{D}=$ Oral papilloma, represented in yellow.

Source: Author

The HPV infection is transmitted primarily through sexual contact (FERNANDES et al., 2013). Both men and women are susceptible to the infection, and can be asymptomatic carriers, transmitters and affected by the infection, all at once in some cases (TRISTÃO et al., 2012). Vaginal or anal penetration is not necessary in order to acquire the infection, considering the fact that the virus can be transmitted by direct contact of the skin or mucosa during intimate contact with the genitals or by the infected surface of other mucous membranes (CUBIE, 2013; FERNANDES et al., 2013). The oncogenic potential of HPV depends on a multiplicity of factors, such viral type, the persistence of the infection and the integration of the viral DNA into the host cell (SANTOS et al., 2013).

Risk factors for HPV infection include: multiple partners, high parity, smoking, drinking, early age of sexual activity onset, and use of oral hormonal medications (FERNANDES et al., 2013; GASPAR et al., 2015; SANTOS, et al., 2016.)

In contrast to data available regarding the prevalence of HPV in the cervical mucosa, little information is available about other potential sites of infection, where the presence of the virus represents a risk factor for cancer (FORMAN et al., 2012). In Brazil, HPV-16 is the most prevalent virus in all regions (BRUNO et al., 2014; SANTOS et al., 2013).

Oliveira et al. (2013) described that in southern Brazil, the prevalence of HPV-16 is evident, followed by HPV-58, HPV-18 and HPV-33, both in high-grade and low-grade lesions. HPV-58 has 
shown a high prevalence, mainly in the Northeast of Brazil (BRUNO et al., 2014). Some studies have suggested an increased risk of infection in HIV patients. (COUTLÉE et al., 1997; PALEFSKY, 2006). Authors are unanimous in stating that subtypes 16 and 18 are the most frequently found in the oral mucosa (FURRER et al., 2006; SYRJÄNEN, 2003). A meta-analysis study showed that the subtype mostly associated with squamous cell carcinoma is HPV-16, followed by 18, 45, 31 and 33 . In adenocarcinomas, the most common is HPV-18, followed by 16 and 45 (CLIFFORD et al., 2003). Ostwald et al. (2003) analyzed the presence of HPV in oral lesions of squamous cell carcinomas, leukoplakia, actinic cheilitis and lichen planus in 267 patients, using the polymerase chain reaction (PCR) technique. It was possible to detect the presence of the virus in $43.2 \%$ of oral carcinomas, with subtypes 16 and 18 being the most frequently associated with these lesions. As for leukoplakia, the presence of the virus was observed in $22.2 \%$ of the cases, with subtype 16 being the most frequently identified, followed by 6 and 11. In actinic cheilitis, HPV was observed in 25\% of cases, with a prevalence of the subtype 16. In lichen planus, detection rates were at $15.4 \%$, with a higher frequency of detection of subtype 18. The results indicated a successive increase in the detection rates of both HPV 16 and 18 in all patients. Especially HPV 16 in samples of patients with lichen planus, leukoplakia, and actinic cheilitis and HPV 18 in samples of squamous cell carcinoma, suggesting an association of high-risk HPV subtype infection (16 and 18) and oral carcinogenesis.

\section{CLINICAL MANIFESTATIONS}

Benign epithelial lesions in the oral cavity include squamous cell papilloma, condyloma acuminatum, common skin wart, focal epithelial hyperplasia and papillary hyperplasia. Comprehensive data on the prevalence of these benign lesions of the oral mucosa are incomplete, without systematic population-based studies. Based on an old survey of 400,000 American children, oral papilloma's were the most common (7.5\%) oral epithelial lesions. Their prevalence was lower in adults, ranging from $0.2 \%$ to $0.4 \%$, most often located on the palate, tongue, lips or gums. (ABBEY et al., 1980).

All of these benign epithelial lesions have been attributed to human papillomaviruses (HPV).

Recently it was demonstrated that both $\beta$ and $\gamma$ HPVs can also be detected in the oral mucosa and / or saliva in asymptomatic infected patients (BOTTALICO et al., 2011), as well as in head and neck carcinomas (SABOL et al., 2016).

The general prevalence of HPV varies according to the anatomical topography, such as the oral cavity (24.2\%), the oropharynx (45.8\%) and the larynx (22.1\%) (D'SOUZA et al., 2007). In a study that investigated lesions located strictly in the oral cavity, the etiological fraction of HPV infections was low (5.9\%) (ANANTHARAMAN et al., 2017). Oral HPV infection is not only associated with but may also precede the onset of oropharyngeal cancer (SHIN et al., 2002). However, there is less evidence available about the relationship between HPV infection and cancer of the oral cavity. 
HPV-associated oral squamous cell carcinoma (OSCC) varies in prevalence by geographic region (D'SOUZA et al., 2007). In a meta-analysis by Ndiaye et al. (2014), although the overall prevalence of OSCC was $24.2 \%$, the prevalence varied widely by continent, from 4.1 to $43.4 \%$ (D'SOUZA et al., 2007).

The INCA (National Cancer Institute of Brazil) estimate for 2019 is 14700 new cases of OSCC in Brazil, 11200 in men and 3500 in women. The estimated number of deaths is 5898, 4672 men and 1226 men.

Human papillomavirus plays an etiological role in oropharyngeal cancer, with $25-50 \%$ of them related to HPV (DE MARTEL et al., 2017; CHATURVEDI et al., 2013). The higher prevalence of oropharyngeal HPV in men has been attributed to the greater propensity to smoke, considering the fact smoking interferes with mucosal immunity, increasing the susceptibility to HPV infection. Women are more likely to generate antibodies after a genital HPV infection than men, providing them some extra protection against oral HPV infection (GIULIANO et al., 2015).

In addition, women have a higher HPV genital viral count, making transmission more likely through male-to-female oral sex than female-to-male (GIULIANO et al., 2015). HIV-infected men are at higher risk of oropharyngeal HPV infection and cancer than HIV-negative men (DELANY-MORETLWE et al., 2013). Data on the prevalence of oropharyngeal HPV infection in low and middle-income countries is limited.

In the oral cavity, HPVs classified as low in oncogenic grade, such as subtypes 6 and 11, are the most frequently detected in benign oral lesions, such as common wart, acuminate condyloma, papilloma and focal epithelial hyperplasia. High-grade oncogenic subtypes, such as 16 and 18, on the contrary, have been strongly associated with squamous cell carcinomas and cancerous lesions, with a high risk of malignant transformation (D'SOUZA et al., 2007).

HPV infection can be classified into: (a) latent, which can only be diagnosed by molecular biology methods; (b) subclinical, in which there are no clinical symptoms, but there are subtle changes that can be diagnosed, by peniscopy, colpocytology, colposcopy and / or biopsy; (c) clinical, in which there are evident lesions on clinical examination (TRISTÃO et al., 2012; XAVIER et al., 2007).

\section{ONCOGENESIS AND THE ROLE OF VIRAL PROTEINS}

There are about 200 different strains of HPV, of which nine are known to cause cancer, and another six are suspected of causing cancer. Among the various strains, HPV-16 is the main concern due to its association with OSCC. HPV-16 is also associated with cervical, anal and penile cancer (HPV ORAL CANCER FOUNDATION, 2019).

Numerous risk factors have been proposed in the oncogenesis of the OSCC, the most significant of them being the use of tobacco. There have been several explanations for the etiology of OSCC 
in a non-smoking population, including the human papilloma virus (HPV) and underlying genetic and transcriptomic changes. In particular, the development of this cancer in a younger, non-smoking population has been of interest to researchers (ZAMMIT et al., 2018).

Patients with HPV-positive OSCC exhibit a reduction in the risk of death by approximately half, compared to patients with HPV-negative tumors. Despite these better results, 10 to $30 \%$ of patients will experience disease progression within three years after the end of their definitive therapy. HPV detection remains a predictor of improvement in overall survival rate for patients who experience progression of loco-regional and / or distant disease after initial treatment (BURR et al., 2018).

In a persistent infection scenario, the viral protein E2 controls the expression of the viral oncoproteins E6 and E7, which are primarily responsible for the formation of the tumor (MOODY; LAIMINS, 2010). In premalignant and malignant lesions, the E2 function is absent, which subsequently leads to uncontrollably higher levels of E6 and E7 expression (RAMPIAS et al., 2009). The inhibition of tumor suppressor proteins $\mathrm{p} 53$ and Retinoblastoma $(\mathrm{pRb})$ alters the cell cycle pathways that regulate cell proliferation, apoptosis, as well as genetic stability, which can ulteriorly lead to the formation of epithelial lesions (AKGEUL, COOKE, STOREY, 2006). The binding of high-risk HPV $\mathrm{E} 7$ protein with $\mathrm{pRb}$, results in the release of the transcription factor $\mathrm{E} 2 \mathrm{~F}$ from $\mathrm{pRb}-\mathrm{E} 2 \mathrm{~F}$ and the consequent formation of the protein complex, promoting the progression of the cell cycle. In addition, it leads to the release of the p16INK4A gene from its transcriptional inhibition. As a consequence, the p16INK4A protein is expressed at high levels and is therefore considered as a reliable substitute marker for high-risk HPV infection (VON KNEBEL DOEBERITZ, 2001).

\section{IDENTIFICATION METHODS}

Direct detection of HPV genomes and their transcripts can be achieved through techniques that include immunohistochemistry, immunofluorescence, hybridizations such as southern blot, northern blot, dot blot, in situ, PCR, hybrid capture, DNA sequencing, among others (FAKHRY et al., 2006). The sensitivity and specificity of the various HPV detection methods vary widely. They are divided into three main categories: those of low sensitivity (immunohistochemistry, immunofluorescence, and in situ hybridization) used for detecting the virus when present in more than 10 copies of viral DNA per cell; those considered to be of moderate sensitivity (southern blot, dot blot, and reverse dot hybridization), detecting the virus when it has one to 10 copies of viral DNA and those of high sensitivity (PCR and hybrid capture), capable of detecting the virus when there is only a fragment - less than one copy of the DNA. (MILLER; JOHNSTONE, 2001). It is possible to extract viral DNA from cervical, anal or oral exfoliated cell samples, salivary rinse, biopsy of suggestive injury oral, cervical or anal (GIPSON et al., 2018). Currently, the two most widely used methods that have 
equivalent sensitivity are the hybrid capture and PCR, with generic primers. There is no safe method to determine the causal virus-disease relationship, although HPV detection is strongly suggestive. The analysis of other important factors such as viral count, seropositivity, and state of virus-host integration and position of infected cells in the epithelium may contribute to determining the exact cause of the lesion, but are not conclusive (HUBBARD, 2003).

\section{ORAL PAPILLOMA}

Viral Papillomas (PVs) cause benign tumors (warts and papillomas) on their natural host; some papillomas induced by specific types of PVs have a high risk of malignant progression (DE VILLERS et al., 2004).

About 50\% of the 223 papillomas analyzed until 1998 were positive for HPV, with HPV-6 and HPV-11 being the predominant genotypes (SYRJANEN, 2010. A more recent study by Dona et al. (2017) reported the presence of HPV DNA in 70\% (22 of 31) of oral papillomas.

Oral squamous papilloma is the most frequent lesion and occurs evenly among men and women, predominantly on the tongue and palate (FERRARO et al., 2011). The common wart has a higher incidence on the lips, and can also be located on the tongue, soft palate and hard palate (CARVALHO, 2016), they are usually isolated lesions, but not necessarily. It is suggested that these lesions can arise by self-inoculation, usually in people who have warts on their hands and fingers (ANTIENZO et al., 2015). Focal epithelial hyperplasia, also known as Heck's disease, is one that differs from the verrucous pattern of these lesions (FERRARO et al., 2011), presenting through papules or nodules, often involving the labial mucosa, occurs predominantly in children (ANTIENZO et al., 2015), this lesion is associated with HPV-13 and HPV-32 (CARVALHO, 2016; RATAUVA et al., 2011).

On other anatomical topographies, such as the genital tract, HPV exclusively infects the basal cells of the epithelium, where it can remain latent. There is evidence that HPV also infects gingival tissue (MADINIER et al., 1992; HORMIA et al., 2005). The periodontal pocket is the only location of the gingival mucosa where basal cells are exposed to the environment. The periodontal pocket increases during the progression of periodontitis as a result of chronic inflammatory processes (TEZAL, 2012). In the presence of chronic inflammation, increased basal cell proliferation leads to a higher viral load in the saliva, as well as an increased risk of HPV transmission. In a hospital-based casecontrol study with histologically confirmed OSCC cases, periodontitis was associated with a more than four-fold risk. This led to the hypothesis that chronic inflammation and continuous epithelial proliferation in the junction gum, could favor HPV replication and could be an important reservoir for HPV in the oral mucosa (STUBENRAUCH, LAIMINS, 1999). 


\section{VACCINES}

Currently, there are three vaccines directed at combating high-risk HPV infections, 2, 4 and 9 valent. The three-use recombinant technology and are prepared from a L1 protein extract. The bivalent (Cervarix $囚$ ) protects against subtypes 16 and 18 , the tetravalent (Gardasil $₫$ ) protects against subtypes 6, 11, 16 and 18 and the nonavalent (Gardasil ${ }^{\circledR}$ 9) protects against subtypes 6, 11, 16, 18, 31, 33, 45, 52, 58 (OLIVEIRA, REGNANI, VILLA, 2019).

Since 2018, the quadrivalent HPV vaccine has been available for the female population aged 9 to 14 years old (14 years, 11 months and 29 days) and for the male population aged 11 to 14 years old (14 years, 11 months and 29 days) with a vaccination schedule of 2 (two) doses ( 0 and 6 months), via "Sistema Único de Saúde” (SUS - Brazil's public universal health system) (MINISTÉRIO DA SAÚDE, 2019).

HPV vaccination is expected to have an impact on oral HPV incidence rates, leastways for genotypes 6, 11, 16 and 18, included in the Gardasil 4 vaccine (BROUWER et al., 2015). Countries with more aggressive vaccination campaigns, such as Australia, already observe a reduction in HPV-related genital warts (ALI et al., 2013; CHOW et al., 2015). However, it has not been clarified yet whether HPV vaccination will in fact reduce the incidence and mortality of HPV-related cancers, as well as whether coverage and adherence to the vaccine will be adequate.

\section{CONCLUSION}

The current criteria for the classification of Papillomaviruses took over 15 years to be assembled, and even today new subtypes are frequently described in research. Many researchers made an attempt at explaining the role of the immune system in the clinical evolution of oral HPV, but many questions still remain unanswered. HPV has been found in malignant lesions of the oral cavity in a non-smoking patient, generating interest in research on oral cancer in non-smokers. Thence, it is believed that research improvement in the development of vaccines is absolutely crucial to understanding the best and safest way to control the disease.

\section{REFERENCE}

ABBEY, L. M.; PAGE, D. G.; SAWYER, D. R. The clinical and histopathologic features of a series of 464 oral squamous cell papillomas. Oral Surgery, Oral Medicine, Oral Pathology and Oral Radiology, v. 49, p. 419-428, 1980.

AKGEUL, B.; COOKE, J. C.; STOREY, A. HPV-associated skin disease. Journal of Pathology, v. 208, p. 165-175, 2006. 
ALI, H.M. et al. Genital warts in young Australians five years into national human papillomavirus vaccination programme: national surveillance data. BMJ (Clinical research ed.), v. 346, p. 2032-2032, 2013.

ANANTHARAMAN, D. et al. Geographic heterogeneity in the prevalence of human papilloma-virus in head and neck cancer. International journal of cancer, p. 1968-1975, 2017.

ANTIENZO, P. C. et al. Presencia del virus papiloma humano en la cavidad oral: revisión y actualización de la literatura. International journal of odontostomatology, v. 9, n. 2, p. 233-238, 2015.

BERNARD, H. U. et al. M. Classification of papillomaviruses (PVs) based on 189 PV types and proposal of tazonomic amendments. Virology, v. 401, p. 17-27, 2010.

BIENKOWSKA-HABA, M.; SAPP, M. The cytoskeleton in papillomavirus infection. Viruses, v. 3, n. 3, p. 260-271, 2011.

BOTTALICO, D. et al. The oral cavity contains abundant known and novel human papillomaviruses from the betapapillomavirus and gammapapillomavirus genera. The Journal of Infectious Diseases, 2011, v. 204, p. 787-792, 2011.

BROUWER, A. F. et al. Trends in HPV cervical and seroprevalence and associations between oral and genital infection and serum antibodies in NHANES 2003-2012. BMC Infectious Diseases, v. 15, p. $575,2015$.

BRUNO, A. et al. Distribuição dos genótipos de papilomavírus humano em mulheres do estado da Bahia, Brasil. Revista Brasileira Ginecologia Obstetrícia, v. 36, n. 9, p. 416-422, 2014.

BURR, A. R. et al. HPV impacts survival of stage IVC non-oropharyngeal HNSCC cancer patients. Otorhinolaryngology Head and Neck Surgery, v. 3, n. 1, 2018.

BUSTOS, D. A. et al. Human papillomavirus infection in cyclosporin: induced gingival overgrowth in renal allograft recipients. Jornal of Periodontology, v. 72, n. 6, p. 741-744, 2001.

CARVALHO, T. C. O viroma oral. Dissertação (Mestrado)- Instituto Superior de Ciências e Saúde Egas Moniz, Almada, p. 81. 2016. 
CHATURVEDI, A. K. et al. Worldwide trends in incidence rates for oral cavity and oropharyngeal cancers. Journal Clinical Oncology, v. 31, p. 4550-4559, 2013.

CHOW, E. P. et al. Ongoing decline in genital warts among young heterosexuals 7 years after the Australian human papillomavirus (HPV) vaccination programme. Sexually Transmitted Infections, v. 91, p. 214-9, 2015.

CLIFFORD, G. M. et al. Human papilomavírus types in invasive cervical cancer worldwide: a meta-analysis. British Journal of Cancer, v. 88, p. 63-73, 2003.

COGGIN, J. R.; ZUR HAUSEN, H. Workshop on papillomavirus and cancer. Cancer Research, v. 39, p. $545-6,1979$.

COUTLÉE, F. et al. Risk factors for oral human papilomavírus in adults infected and not infected with human immunodeficiency virus. Sexually Transmitted Infections, v. 24, n. 1, p. 23-31, 1997.

CRAWFORD, L. V. ; CRAWFORD, E. M. A comparative study of polyoma and papilloma viruses. Virology, v. 21, n. 2, p. 258-263, 1963.

D'SOUZA, G. et al. Six-month natural history of oral versus cervical human papillomavirus infection. International Journal of Cancer, v. 121, p. 143-50, 2007.

D'SOUZA, G. et al. Oral sexual behaviors associated with prevalent oral human papillomavirus infection. Journal of Infectious Diseases, v. 199, n. 9, p. 1263-9, 2009.

D'SOUZA, G. et al. Case-control study of human papillomavirus and oropharyngeal cancer. New England Journal of Medicine, v. 356, p. 1944-1956, 2007.

DE MARTEL, C. et al. Worldwide burden of cancer attributable to HPV by site, country and HPV type. International Journal of Cancer, v. 141, p. 664-670, 2017.

DE VILLERS, E. M. et al. Classification of papillomaviruses. Virology, v 324, n. 1, p 17-27, 2004.

DE VILLERS, E. M.; GUNST, K. Characterization of seven novel human papillomavirus types isolated from cutaneous tissue, but also present in mucosal lesions. Journal of General Virology, v. 90, p. 1999-2004, 2009. 
DE VILLERS, E. M. Cross-roads in the classification of papillomaviruses. Virology, v. 445, p. 2-10. 2013.

DELANY-MORETLWE, S.; CHIKANDIWA, A.; GIBBS, J. Human papillomavirus infection and disease in men: impact of HIV. The Southern African Journal of HIV Medicine, v. 14, p. 183-188, 2013.

DONA M. G., et al. Mucosal and cutaneous human papillomaviruses in head and neck squamous cell papillomas. Head Neck, v. 39, p. 254-259, 2017.

EGAWA, N. et al. Human papillomaviruses: epithelial tropisms, and the development of neoplasia. Viruses, v. 7, n. 7, p. 3863-3890, 2015.

FAKHRY, C. et al. Relationship between Prevalent Oral and Cervical Human Papillomavirus Infections in Human Immunodeficiency Virus-Positive and Negative Women. Journal of Clinical Microbiology, v. 44, n. 12, p. 4479-4485, 2006.

FAUQUET, C. M. et al. Revison of taxonomic criteria for species demarcation in the family Geminiviridae, and an updated list of begomovirus species. Archives of Virology, v. 148, n. 2, p. 405-21, 2003.

FAUQUET, C. M. et al. Virus Taxonomy, Eighth Report of the International Committee on Taxonomy of Viruses. Elsevier/Academic Press, 2005.

FAVRE, M. et al. Human papillomavirus DNA: physical map. Proceedings of the National Academy of Sciences, v. 72, n. 12, p 4810-4, 1975.

FAY, A. et al. The positively charged termini of L2 minor capsid protein required for bovine papillomavirus infection function separately in nuclear import and DNA binding. Journal of Virology, v. 78, p. 13447-13454, 2004.

FERNANDES, J. V. et al. Biology and natural history of human papillomavirus infection. Open Access Journal of Ophthalmology, v. 5, p. 1-12, 2013.

FERRARO, C. T. L. et al. Infecção oral pelo HPV e lesões epiteliais proliferativas associadas. Jornal Brasileiro de Patologia, v. 47, n. 4, p. 451- 459, 2011.

FORMAN, D. et al. Global burden of human papillomavirus and related diseases. Vaccine, v. 30, n. jan. , p. 12-23, 2012. 
FURRER, V. E. et al. Biopsy vs. superficial scraping: detection of human papilomavírus 6,11,16 e 18 in potencially malignant and malignant oral lesions. Journal of Oral Pathology \& Medicine, v. 35, n. 6, p. 338-344, 2006.

GANGULY, N. ; PARIHAR, S. P. Human papillomavirus E6 and E7 oncoproteins as risk factors for tumorigenesis. The Journal of Biosciences, v. 34, n. 1, p. 113-23, 2009.

GASPAR, J.; QUINTANA, S. M.; REIS, R. K. Factores sociodemográficos y clínicos de mujeres con el VPH y su. Revista Latino-Americano Enfermagem, v. 23, n. 1, p. 74-81, 2015.

GIPSON, B. J. et al. Sensitivy and specificity of oral HPV detection for HPV-positive head and neck cancer. Oral oncology, v. 77, p. 52-56, 2018.

GIULIANO, A. R. et al. EUROGIN 2014 roadmap: differences in human papillomavirus infection natural history, transmission and human papillomavirus-related cancer incidence by gender and anatomic site of infection. International Journal of Cancer, v. 136, p. 2752-2760, 2015.

HA, P. K.; CALIFANO, J. A. The role of human papillomavirus in oral carcinogenesis. Critical Reviews in Oral Biology \& Medicine, v. 15, n. 4, p. 188-196. 2004.

HENNESSEY, P. T.; WESSTRA, W. H.; CALIFANO, J. A. Human papillomavirus and head and neck squamous cell carcinoma: recent evidence and clinical implications. Journal of Dental Research, v. 88, n. 4, p. 300-306, 2009.

HORMIA, M. et al. Marginal periodontium as a potential reservoir of human papillomavirus in oral mucosa. The Journal of Periodontology, v. 76, n. 3, p. 358-363, 2005.

HPV ORAL CANCER FOUNDATION. Disponível em: https://bit.ly/3bWIklF. Acesso em: 19 de junho de 2019.

HUBBARD, R. A.; Human papillomavirus testing methods. Archives of Pathology \& Laboratory Medicine. v. 127, n. 8, p. 940-945, 2003.

HÜBBERS, C. U.; AKGÜL, B. HPV and cancer of the oral cavity. Virulence, v. 6, n. 3, p. 244-248, 2015. 
INCA INSTITUTO NACIONAL DO CÂNCER. Disponível em: https://bit.ly/3bVujof. Acesso em: 19 de julho de 2019.

KOONIN, E.V. et al. Global Organization and Proposed Megataxonomy of the Virus World. Microbiology and Molecular Biology Reviews, v 84, n. 2, p. 61-19, 2020.

LETO, M. G. P. et al. Human papillomavirus infection: etiopathogenesis, molecular biology and clinical manifestations. Anais Brasileiros de Dermatologia, v. 86, n. 2, p. 306-317, 2011.

LONGWORTH, M. S.; LAIMINS, L. A. Pathogenesis of human papillomaviruses in differentiating epithelia. Microbiology and Molecular Biology Reviews, v. 68, n. 2, p. 362-72, 2004.

MADINIER, I.; DOGLIO, A. et al. Southern blot detection of human papillomaviruses (HPVs) DNA sequences in gingival tissues. The Journal of Periodontology, v. 63, p. 667-73, 1992.

MANOS, M. M. et al. The use of polymerase chain reaction amplification for the detection of genital human papillomaviruses. Cancer Cells, v. 7, p. 209-214. 1989.

MILLER, C. S.; JOHNSTONE, B. M. Human papillomavirus as a risk factor for oral squamous cell carcinoma: a metanalysis, 1982-1997. Cirurgia Oral, Medicina Oral, Patologia Oral e Radiologia Oral, v. 91, p. 622- 635, 2001.

MINISTÉRIO DA SAÚDE. Disponível em: https://bit.ly/2Kwjduu. Acesso em 18 de julho de 2019.

MOODY, C. A.; LAIMINS, L. A. Human papillomavirus oncoproteins: pathways to transformation. Nature Reviews Cancer, v. 10, p. 550-60, 2010.

MORSHED, K. et al. Human papillomavirus (HPV): structure, epidemiology and pathogenesis. Otolaryngologia Polska., v. 68, p. 213-219, 2014.

MUÑOZ, N. et al. Epidemiologic classification of human papillomavirus types Associated with Cervical Cancer. New England Journal of Medicine, v. 348, p. 518-527, 2003.

NDIAYE, C. et al. HPV DNA, E6/E7 mRNA, and p16INK4a detection in head and neck cancers: a systematic review and meta-analysis. Lancet Oncology, v. 15, p. 1319-1331, 2014. 
OLIVEIRA, L; SANTOS L; NEVES F. Characterization of a new genotype of Betapapillomavirus HPV 17 through L1, E7, E7 and LCR sequences. Acta Virologica, v. 62, n. 2, p 172-178. 2018.

OLIVEIRA, C. M.; FREGNANI, J.H.T.G.; VILLA, L.L. HPV vaccine: Updates and Highlights. Acta Cytologica., v. 63, p 159-168. 2019.

OSTWALD, C. et al. Human papilomavirus 6/11, 16 and 18 in oral carcinomas and benign oral lesions. Medical Microbiology and Immunology, v. 192, n. 3, p. 145-8, 2003.

PALEFSKY, J. Biology of HPV in HIV Infection. Advances in Dental Research, v. 19, p. 99-105, 2006.

PSYRRI, A.; DIMAIO, D. Human papillomavirus in cervical and head-and-neck cancer. Nature Clinical Practice Oncology, v. 5, n. 1, p. 24-31, 2008.

RAMPIAS, T. E6 and e7 gene silencing and transformed phenotype of human papillomavirus 16-positive oropharyngeal cancer cells. Journal of the National Cancer, v. 101, p. 412-23, 2009.

RAUTAVA, J. R.; SYJÄNEN. S. Human papillomavirus infections in the oral mucosa. Journal of the American Dental Association, Rome, v. 142, n. 8, p. 905-914, 2011.

SABOL, I. et al. Beta-HPV types in patients with head and neck pathology and in healthy subjects. Journal of Clinical Virology, v. 82, p. 159-165, 2016.

SANTOS, C. A. et al. Incidência de HPV em clientes soropositivos para HIV- Uma revisão bibliográfica. Revista Faculdade Montes Belo (FMB), v. 9, n. 2, p. 17-27, 2016.

SANTOS, J. C. et al. Ocorrência de papilomavírus humano na cérvice uterina de mulheres da região ocidental da Amazônia Brasileira. Acta Amazonica, v. 43, n. 2, p. 185-190, 2013.

SAPP, M.; BIENKOWSKA-HABA, M. Viral entry mechanisms: human papillomavirus and a long journey from extracellular matrix to the nucleus. FEBS Journal, v. 276, n. 24, p. 7206-7216, 2009.

SHIN, K. H. et al. Prevalence of microsat- ellite instability, inactivation of mismatch repair genes, p53 muta- tion, and human papillomavirus infection in Korean oral cancer patients. International Journal of Oncology, v. 21, p. 297-302, 2002. 
SOUZA, T. R. B.; GONÇALVES, A. J. Papilomavírus humano e a detecção do DNA viral no carcinoma espinocelular da cavidade oral. Revista Brasileira Cirurgia Cabeça Pescoço, v. 38, n. 1, p. 62-66, 2009.

STAUFFER, Y. et al. Infectious human papillomavirus type 18 pseudovirions. Journal of Molecular Biology, Amsterdam, v. 283, p. 529-536, oct. 1998.

STRAUSS, M. J. et al. "Crystalline” virus-like particles from skin papillomas characterized by intranuclear inclusion bodies. The Society for Experimental Biology and Medicine, p. 72-46, 1949.

STUBENRAUCH, F.; LAIMINS, L. A. Human papillomavirus life cycle: active and latent phases. Seminars in Cancer Biology, v. 9, p. 379-386, 1999.

SUN, F. et al. Human papillomavirus 16 E6 gene mutation in cervical carcinoma tissues. Ai Zheng Chen, v. 28, n. 5, p. 478-482, 2009.

SYRJÄNEN, K. HPV infection in benign and malignant sinonasal lesion. Journal of Clinical Pathology, v. 56, n. 3, p. 174-181, 2003.

SYRJÄNEN, S. Current concepts on human pappilomavirus infections in children. APMIS, v. 118, p. 494-509, 2010.

TEZAL, M. Interaction between Chronic Inflammation and Oral HPV Infection in the Etiology of Head and Neck Cancers. International Journal of Otolaryngology, 2012.

TRISTÃO, W. et al. Epidemiological study of HPV in oral mucosa through PCR. Brazilian Journal of Otorhinolaryngology, v. 78, n. 4, p. 66-70, 2012.

VON KNEBEL, D. M. New molecular tools for efficient screening of cervical cancer. Disease Markers, v. 17, p. 123-128, 2001.

WAGGONER, E. S. Cervical cancer. Lancet, v. 361, n. 9376, p. 2217-2225, 2003. 
XAVIER, S. D. et al. Frequência de aparecimento de Papilomavírus Humano (HPV) na mucosa oral de homens com HPV anogenital confirmado por biologia molecular. Arquivos Internacionais de Otorrinolaringologia, v. 11, n. 1, p. 36-44, 2007.

ZAMMIT, A. P. et al. Examining the contribution of smoking and HPV towards the etiology of oral cavity squamous cell carcinoma using high-throughput sequencing: A prospective observational study. PLoS One., v. 13, n. 10, 2018. 